\title{
DESIGN DEVELOPMENT AND IMPLEMENTATION OF ANDROID-BASED ELECTROCARDIOGRAM READER
}

\author{
Sumiati \\ Universitas Serang Raya-Banten \\ Haris Triono Sigit \\ Universitas Serang Raya-Banten
}

\author{
Kusprianto \\ Teknik Biomedika, ITB, Bandung, Indonesia
}

Hasballah

Teknik Biomedika, ITB,Bandung

Abstract: Heart disease is the number one cause of death in the world. Heart disease is one of the most common diseases and one of the highest
causes of death in Indonesia (Ministry of Health, 2017). Health disease isn't easy to detect because it can't be seen physically, requiring a tool to
monitor heart condition, i.e. Electrocardiogram (ECG). Although the result of electrocardiogram measurement is time graph to voltage called
electrocardiogram (ECG), it can analyze and identify patient's heart condition automatically, only displaying seven criteria in interpreting
Electrocardiogram (ECG) result, i.e. Heart Rate, Rhythm), P Wave, P-QRS Distance (PR Interval), QRS Complex (PR Interval), QRS Complex, S T
Segment and T Wave. Therefore, it requires specialist ability to interpret the result of measurement of heart muscle activity. That's why there are
many cases of heart disease which are treated late, because analysis takes a long time. Despite obtaining ECG data, it's difficult to know information
in ECG record result. To read ECG record, one must have experience and knowledge on health disease and its symptoms. Manual extraction of
important information of signals in ECG is very inefficient due to the amount of data to observe. Keyword: Heart Disorder, Electrocardiogram, Android, Heart Rate, QRS

\section{INTRODUCTION}

. Heart disease is the number one cause of death in the world. Heart disease is one of the most common diseases and one of the high cause of death in Indonesia (Ministry of Health, 2017). Health disease isn't easy to detect because it can't be seen physically. One should be aware of heart disease and immediately take measures to treat it because it happens suddenly, almost all patients have no previous complaint, and the patients generally look very healthy, requiring a tool to monitor heart condition, i.e. Electrocardiogram (ECG).

ECG can record the 'electrical' activities of the heart. Coronary blockage in the heart with 'ischemia' causes disturbance in the heart's 'electrical' activities which are detected by 'electrocardiogram '. ECG also can record various disorders of the electrical activities of the heart. ECG can determine the possibility of heart defect with $40 \%$ accuracy using sound waves to produce heart image. During the process, doctor can determine all parts of heart walls have normal contribution in pumping the heart. Weakly moving part may have been damaged during heart attack or receive too little oxygen. This may indicate coronary artery or other conditions. ECG examination can record the 'electrical' activities of the heart. Coronary blockage in the heart with 'ischemia' causes disturbance in the heart's 'electrical' activities which are detected by 'electrocardiogram '. ECG also can record various disorders of the electrical activities of the heart.

\section{RELATED WORKS}

\subsection{Heart}

The definitions of heart disease and heart attack are different. Heart attack is a condition which causes the heart to not work at all. 


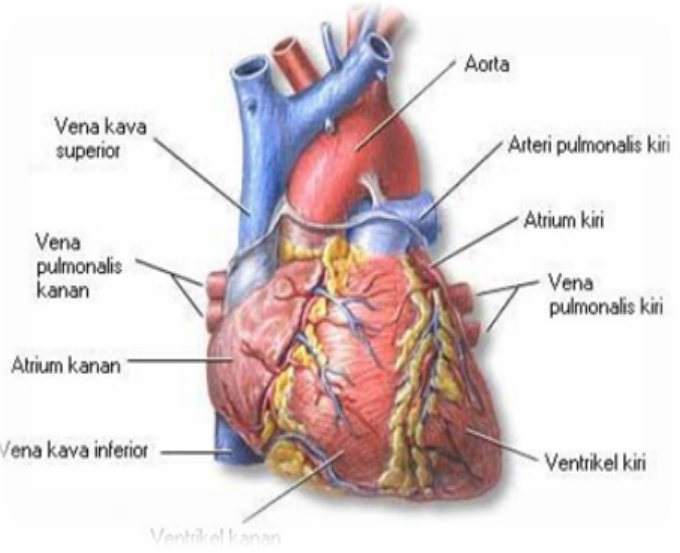

Fig 1. Heart

This condition usually happens suddenly and is often referred to as heart failure. The causes of heart failure vary, but the main cause is usually blocked blood supply to cardiac muscles because the blood vessels which usually deliver blood to the cardiac muscles are blocked or hardened due to fat and cholesterol, or chemicals, e.g. excessive usage of drugs which contain Phenylpropanolanin (ppa) which is often found in drugs such as Decolgen, and nicotine. (source:wikipedia). However, heart disease is a dangerous often lead to death of the patients. Patients often know about their heart diseases too late, therefore they receive treatment too late.

\subsection{Heart Rhythm}

Heart rhythm is within normal range if it has sinus rhythm which comes from impulse located near the mouth of vena cava superior in the right atrium of the heart. Sinus rhythm is a rhythm which has q wave which is followed by QRS complex. The distance between the same waves is similar and regular. So, sinus rhythm is $p$ wave and every $p$ wave must be followed by QRS complex. Meanwhile, non-sinus rhythm has no QRS complex after $\mathrm{P}$ wave or no $\mathrm{P}$ wave at all.

\subsection{Interpretation of ECG Examination Result}

\section{Morphology of ECG Wave}

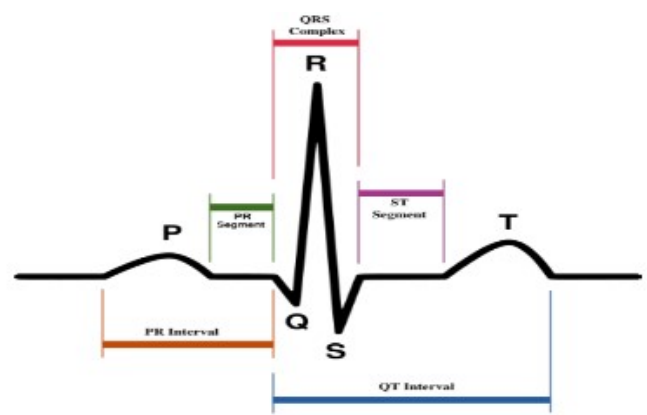

Fig 2. Morphology of ECG Wave

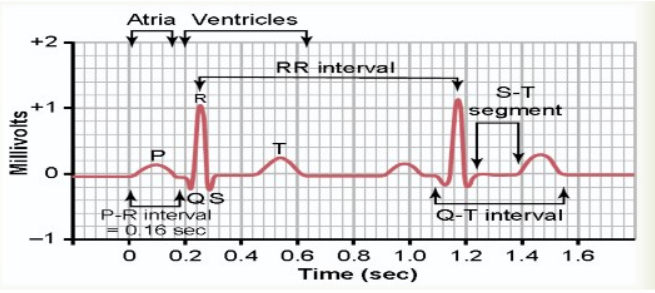

Fig 3. Morphology of ECG Wave

\section{DESIGNING SYSTEM}

\subsection{Designing System}

Use Case Diagram

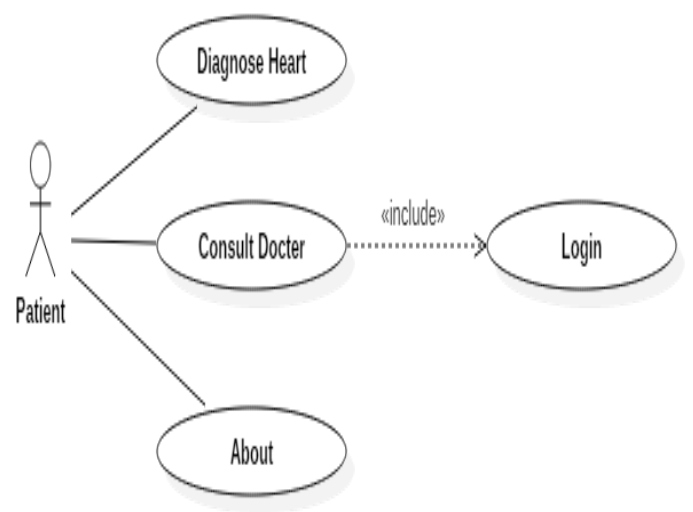

Fig 4 : Use Case Diagram 
Activity Diagram

Activity diagram login describes login process by user to enter a system. It's shown in the figure of activity diagram below

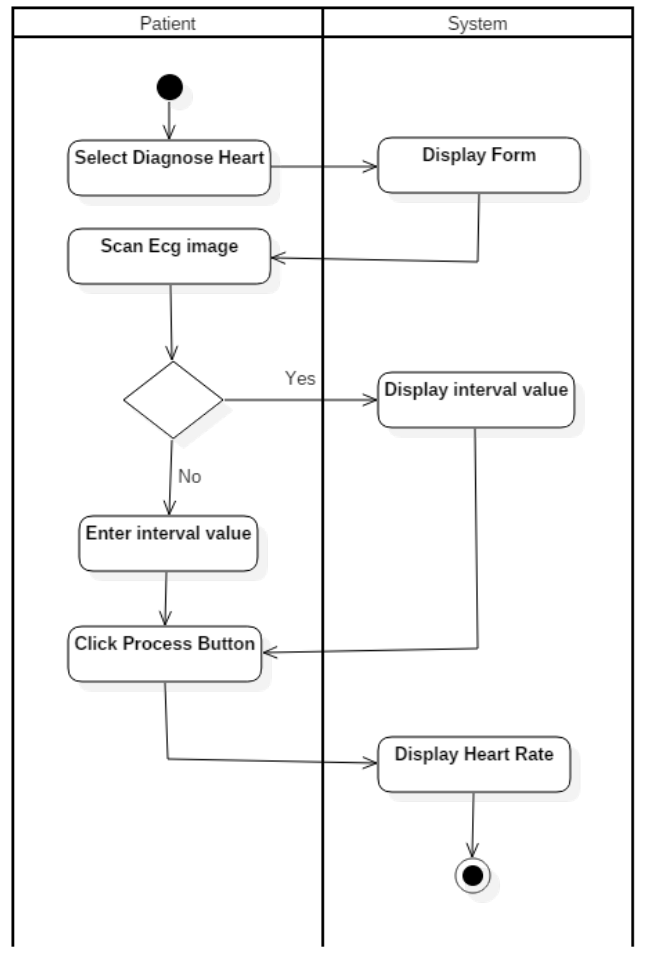

Fig 5. Activity Diagram of Diagnose Heart

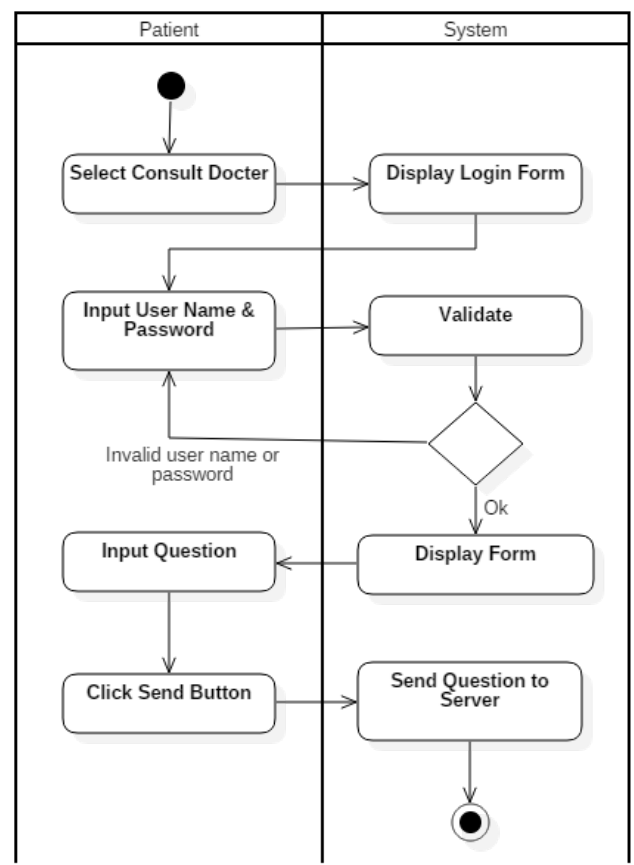

Fig 6. Activity Diagram of Consult Docter
Activity Login.

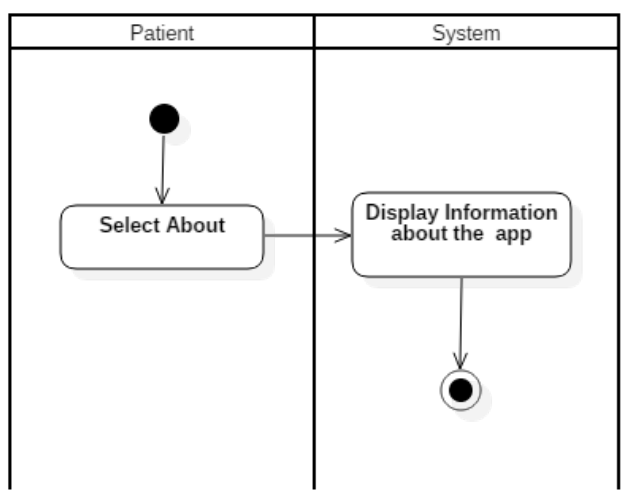

Fig. 7 Activity Diagram of About

\subsection{System Testing}

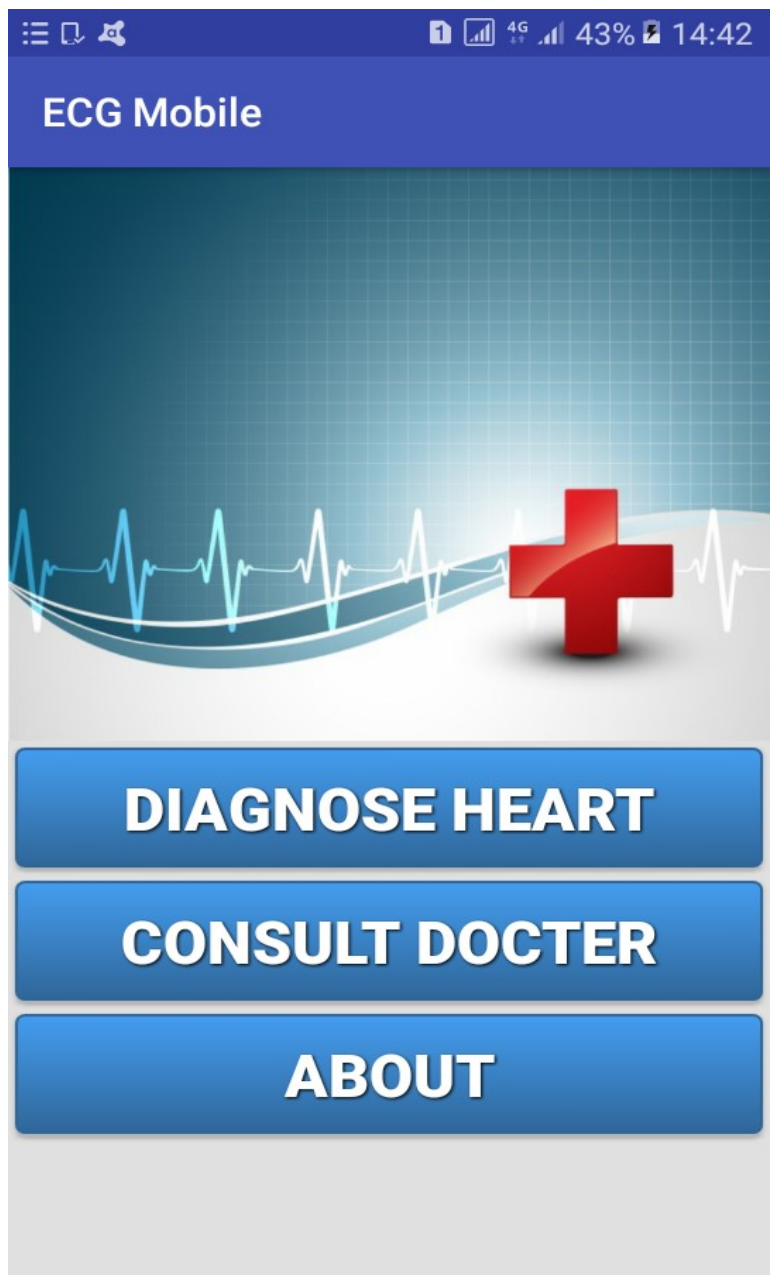

Fig.8 Initial Display of the Application 


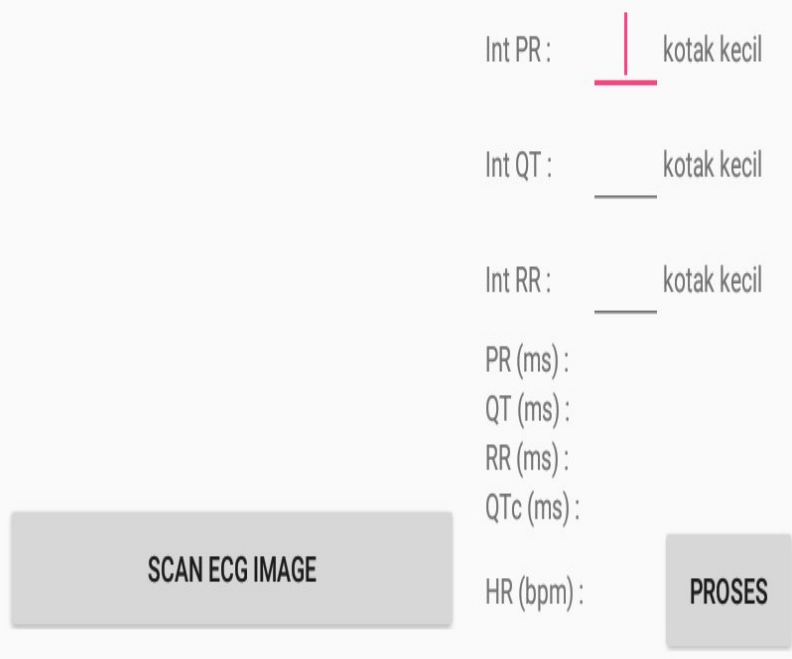

Fig. 9 Display of Heart Diagnosis

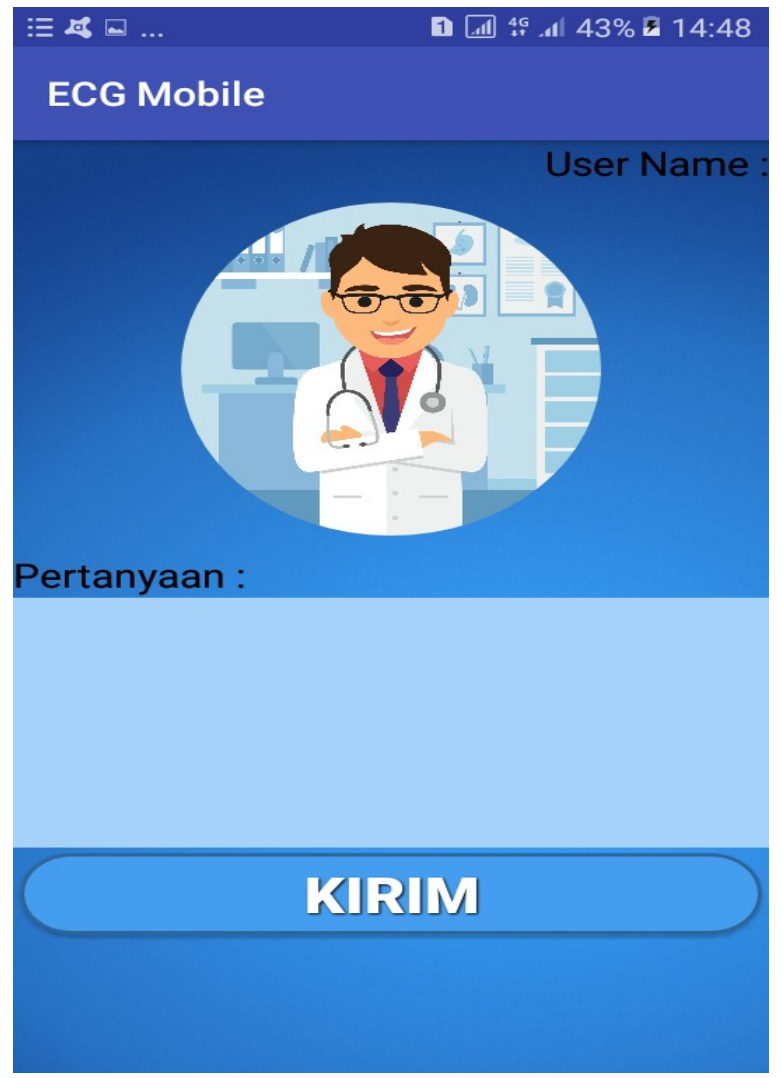

Fig 11. Display of Consult Doctor

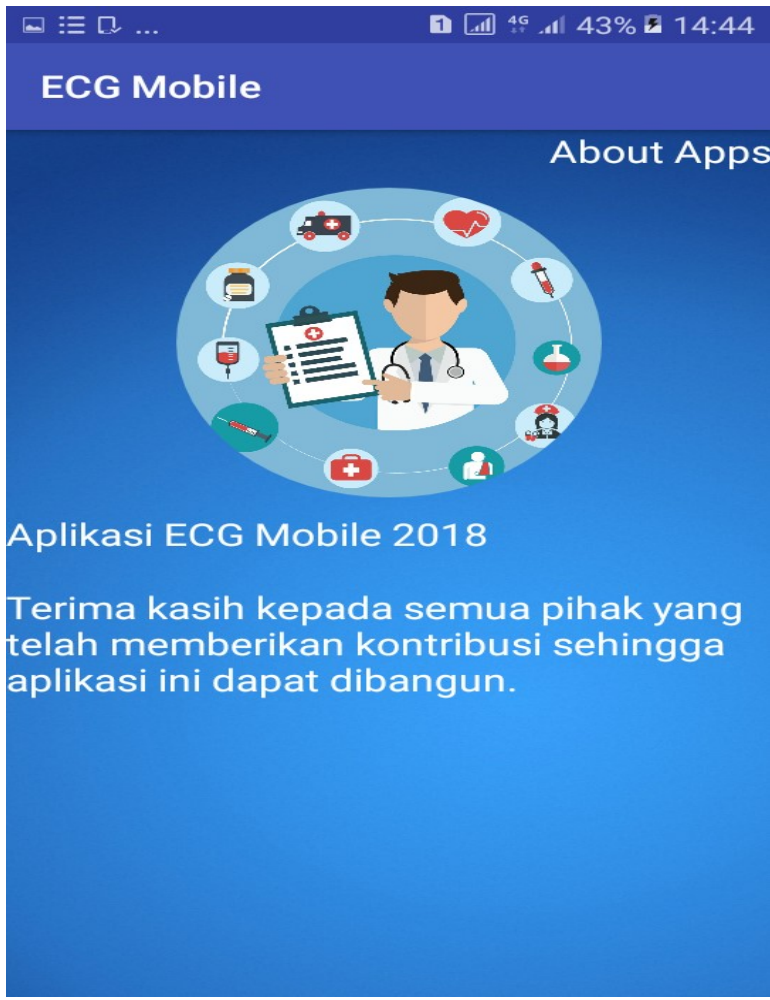

Fig. 12.Display of About Application

\section{CONCLUSION}

Representation of heart rate wave was obtained by developing design and implementing android -based electrocardiogram reader

\section{REFERENCES}

[1] Antoni Rogalski, 2011, Infrared Detector, 2nd Edition, CRC Press, Taylor \& Francis Group, USA.

[2] Agustina.et al" Implementasi Telemedicine menggunakan IPATH"

[3] Atalapu, Putri. (2012) "Implementasi Location Based Srvice Berbasis Cell Id Untuk Anjungan Provinsi Suawesi Selatan Taman Mini Indonesia Indah (TMII) Memanfaatkan Teknologi Augmented Reality". Jurnal Teknik Informatika. hlm. 3

[4] Backman.W. et al. ( 2010 ). The telecardiology revolution: improving the management of cardiac disease in primary care. Journal of Royal socieyy of Medicine: 10.1258.

[5] Computer Vision Test Image. (n.d.). Retrieved May 04, 2011, from Computer Vision Homepage: http://www.cs.cmu.edu/ cil/v-images.html

[6] C. S. Pattichis, E. Kyriacou, S. Voskarides, M. S. Pattichis, R. Istepanian, "Wireless telemedicine Systems: An Overview," IEEE Antennas and Propagation Magazine, vol 44, no. 2, pp.143-153, 2002.

[7] Dr Jem Rashbass and Professor Peter Furness,2005,Telepathology: Guidance from The Royal College of Pathologists

[8] D.Giansanti, L.Castrichella, and M.R. Giovagnoli, Telepathology Requires Specific Training for the Technician in the Biomedical Laboratory, TELEMEDICINE and e-HEALTH Vol. 14 No. 8,October 2008 
[9] E. Kyriacou, M.S. Pattichis, C.S. Pattichis, A. Panayides, and A. Pitsillides, "m-Health e-Emergency Systems: Current Status and Future Directions," IEEE Antennas and Propagation Magazine, vol. 49, no.1, pp. 216-231, Feb. 2007.

[10] Eung Seok Lee, M.D,et all,2002, Practical Telepathology Using a Digital Camera and the Internet,telemedicine journal and ehealth volume 8 , number 2

[11] Goh .K.W. et al. ( 2006 ).Issues in implementing a knowledge based ECG analyzer for personal mobile health monitoring.Confrence Proceedings. IEEE . Engineeringin Medical and Biology Society .1:6265-6268,New York,Ny, ISSN 1557-170X.

[12] G. E. Moore, "Cramming more components onto integrated circuits," Electronics, vol. 38, no. 8, Apr. 1965

[13] Gamira, Rina. Telkom Kembangkan Aplikasi Telemedicine. www.MediaIndonesia.com , dipublikasikan Kamis 10 Mei 2012, diakses 10 Mei 2012.

[14] N. Rutt et al, 2005, Infrared Physics \& Technology, Volume 16, Elsevier, USA.

[15] H. S. Ng, M. L. Sim, C. M. Tan, and C. C. Wong, "Wireless technologies for telemedicine," BT Technology Journal, Springer Netherlands, vol. 24, no. 2, pp. 130-137, 2006

[16] Helmut Budzier, Gerald Gerlach, Thermal Infrared Sensors: Theory, Optimisation and Practice, USA

[17] Hailey. D. et al . ( 2004). Published evidenceon the success of telecardiology: Amixed record. Journal of Telemedicine and telecare.Vol.10,Suppl1,pp.36-38,ISSN 1357-633\%

[18] Hariyati RTS, \& Sahar J. ( 2012 ). Perceptions of Nursing Care for cardiovascular cases, Knowledge on the Telehealth and Telecardiology in Indonesia. International Journal of Collaborative Research on Internal Medicine \& Public health; 4(2):116-128.

[19] Iman Soeharto, 2004, Penyakit Jantung Korone dan Serangan Jantung: Panduan bagi Masyarakat Umum, Gramedia Pustaka Utama, Indonesia.

[20] Ilmu Patologi Anatomi Kurang Diminati. Republika Online. Diakses pada 2 Februari 2008

[21] John R. Cameron, James G.Skofronik, Roderick M. Grant, 1999, Physics of the Body, 2nd Edition, Medical Physics Publishing Corpo, USA.

[22] J. Settakorn, T. Kuakpaetoon, F.J.W.-M. Leong, K. Hamprasert, and K. Ichijima, Store-and-Forward Diagnostic Telepathology of Small Biopsies by E-Mail Attachment: A Feasibility Pilot Study with a View for Future Application in Thailand Diagnostic Pathology Services, Telemedicine Journal And E-Health, Volume 8, Number 3, 2002

[23] Jie Zhou, M.A. Hogarth, R.F. Walters, R.Green, and T.S. NESBITT, Hybrid System for Telepathology, Human Pathology, Volume 31, No. 7 July 2000

[24] Kusumadewi, Sri, dkk. Informatika Kesehatan. Graha Ilmu. Yogyakarta. 2009

[25] Liberman. J. et al. ( 2008 ). How telemedicine is aiding prompt ECG diagnosis in primary care .Br J Community Nurs;13:123-6

[26] Leonard S L.( 2005 ). Pathophysiology of Heart Disease. Philadelpia: Lippincott Williams \& Wilkins.
[27] Molinari. G. et al. ( 2002 ) The role of telecardiology in supporting the decition -making process of general practitioners during the management of patients with suspected cardiac event. J Telemed Telecare;8:9-101

[28] Martinez A, Villarroel V, Seoane J, Del Pozo F Rural telemedicine for primary health care in developing countries, IEEE Technology and society magazine, Summer 2004.p 1322

[29] National Clinical Guideline For Acute and Chronic ( 2010 ).NICE Clinical Guideline 95.Chest pain of recent onset. Assement and diagnosis of recent onset chest paint or discomfort of suspected cardiac origin. London: NICE.

[30] Pattichis CS, Kyriacou E, Voskarides S, Pattichis MS, Instepanian R, Schizas CN. Wireless telemedicine systems : an overview ,IEEE Antennas 7 Propogation Magazine 2002;44(2):p.143-53

[31] R. Howard Swanton, Shrilla Banerjee, 2008, Swanton's Cardiology, 6th Edition, Blackwell Publishing, WileyBlackWel, USA.

[32] . R.H. Istepanian, S. Laxminarayan, and C.S. Pattichis, Eds, MHealth: Emerging Mobile Health Systems. New York: Springer, 2006, ch. 3.

[33] R.S.Weinstein, M.R. Descour, Chen Liang, L.Richter, W.C. Russum, J.F.Goodall, Pixuan Zhou, A.G.Olszak, and P.H. Bartels, Reinvention of Light Microscopy:Array Microscopy and Ultrarapidly Scanned Virtual Slides for Diagnostic Pathology and Medical Education, May 11, 2005

[34] Syaifuddin, 1997, Anatomi Fisiologi Untuk Siswa Perawat, Edisi 2. Penerbit Buku Kedokteran EGC, Jakarta, Indonesia.

[35] Stephen Black-Schaffer, M.D.,Thomas J. Flotte, M.D,1995, Current Issues in Telepathology,Telemedicine Journal Volume 1, Number 2, Mary Ann Liebert, Inc

[36] Scalvini, S. \& Glisenti, F.( 2005 ).Centenary of teleelectrocardiography and telephonocardiography. Where are we today?. J Telemed Telecare; 11: 325-30

[37] Sutjiredjeki E, Soegijoko S, Mengko TLR, Tjondroaegoro S.Development of mobile telemedicine system with rnulti communication links to reduce malernal mortality rate, Proc. Of The Sixth International Association of Science and Technology for Development (IASTED) latemational Conf. on Biomedical Engineering 2008, Innsbruck, Austria, p.137 $-42$

[38] Sumiati.et al (2017). Telemedicine Systems For Electrokardiogram to Improve Public Health Services. International Journal of Computer Application (0975-8887) Voulume 176 No.6 Oktober 2017.

[39] Telkelsen.C.J. et al. (2002 ).Telemedicine used for remote prehospital diagnosing in patients suspected of acute myocardial infarction. J Intern Med;252:412-20

[40] Yukako Yagi et all,1999,Clinical Guidelines for Telepathology,American Telemedicine Association

[41] Ziad O. Abu-Faraj, 2012, Handbook of Research on Biomedical Engineering Education and Advanced Bioengineering Learning: Interdisciplinary Concepts, Medical Information Science Refernce, IGI Global, USA. 